Geront. clin. 1963;5:251-252

\title{
Index rerum ad Vol. 5
}

(S) = Society Transactions - Gesellschaftsberichte - Sociétés

Anaemia, macrocytic, fat absorption

studies, 30 -, pernicious, in elderly, 23 Aspirin in the treatment of diabetes

mellitus, 234 Atherosclerosis, surgical management of

peripheral ischaemia, 209

Bedford, P.D. Dr., obituary, 128

Blood sedimentation rate, haemostasis in

elderly, 103 Blutzellsystem, weißes, alternsabhängige

Veränderungen, 45 British Geriatrics Society, -, autumn meeting, 189 (S) -, Northern Branch, 190 (S) Bronchial carcinoma, 193 Bronchopneumonia, causes of death in

nonagenarians, 139

Calcified heart valves, unusual radio-graphic shadow, 52 Calcium and vitamin D, treatment of high serum alkaline phosphatase

levels, 203 Cancer, inoperable, cyclophosphamide,

226 Carcinoma, thoracic surgical patients,

193 Cardia carcinoma, 193 Care for the mentally sick old person, 72 - of the aged, neurosurgery, 77 -, residential, of the disabled aged, 38 Cerebral-vascular disease, obesity, 87 Cerebro-vascular degenerative disorders,

leptazol and nicotinic acid, 95 Cholesterol, haemostasis in elderly, 103 Clotting mechanism, in elderly patients,

103

Cyclophosphamide, in cases of inoperable cancer, 226

Death, causes, in nonagenarian, 139 Dementia, care of sick old person, 72 Depression in elderly patients with sub-nutrition, 215 Diabetes mellitus, aspirin, 234

Elderly, disabled-infirm, residential care,

38 -, social attitude as a guide to hospital

placement, 1 -, steatorrhoea, 30 -, tests with toys, 8 Endoxana, in cases of inoperable cancer, 226 Euglobulin clot lysis time, haemostasis in

elderly, 103

patients, 144

test, venous thrombosis in surgical

Fibrinogen, haemostasis in elderly, 103 Fibrinolysis mechanism, in elderly patients, 103 Folic acid, megaloblastic anemia, 163 Freedom-from-fear, a home care achievement, 244

Gastric ulcer, giant innocent, in the

elderly, 171 Granulocyten, neutrophile, Kernsedi-

mentierungsgrad im Greisenalter, 45

Heart valves, calcified, unusual radio-graphic shadow, 52

Haemostasis, investigations in elderly, 103

Index rerum 
Heparin tolerance test, haemostasis in elderly, 103

Home care achievement, freedom-from-fear, 244

Hospital, geriatric and mental, misplacement of elderly, 1

International Association of Gerontology, sixth international congress, 63 (S)

Ischaemia, peripheral, surgical management, 209

Italian Society of Gerontology and Geriatrics, 11th national congress, 250 (S)

Leptazol, chronic cerebro-vascular degenerative disorders, 95

Leukocyten, osmotische Resistenz im hohen Alter, 45

Megaloblastic anemia, folic acid, 163 Memory disorders in elderly, sedation

and sleep thresholds, 55 Mental hospital, misplacement of elderly,

1 Mentally sick old person, adequate care,

72 Misclassification of mentally sick old

person, 72

Nervus ulnaris, Leitungsgeschwindig-keit, bei sehr alten Menschen, 231

Neurosurgery, care of the aged, 77

Nicotinic acid, treatment of chronic cerebro-vascular disorders, 95

Nonagenarians, causes of death, 139

Obesity in chronic cerebral-vascular

disease, 87 Oesophagus carcinoma, 193 Osteoporosis and osteomalacia, senile,

203

Pernicious anaemia, in elderly, 23 Phenolsulfonphthalein excretion test,

residual urine, 65 Plasminogen, haemostasis in elderly, 103 Prothrombin time, haemostasis in elderly, 103

Sedation threshold in elderly patients

with memory disorders, 55 Serum alkaline phosphatase, raised, 203 Sleep threshold in elderly

patients with

memory disorders, 55 Social attitude as a guide to hospital

placement of the elderly, 1 Spinal tumours, in the aged, 77 Subnutrition, depression in elderly

patients, 215 Steatorrhoea in the elderly, 30 Sway, control, effect of age, 129

Thoracic surgery, in the elderly, 193 Thrombelastography, haemostasis in

elderly patients, 103 Thrombosis, venous, in surgical patients,

144 Thymoleptic drugs, depression in elderly

patients with subnutrition, 215 Toys, test in old people, diagnostic

value, 8

Ulcer, giant innocent gastric, in the

elderly, 171 Urine, residual, in aged women, 65

Vital capacity, in normal persons of 70

years, 155 Vitamin B12 und Kernsedimentierung,

$45-\mathrm{D}$ and calcium, treatment of high

serum alkaline phosphatase levels,

203 